\title{
Why we need binarism to go beyond it
}

\author{
Elrud Ibsch
}

Published online: 13 October 2010

(C) The Author(s) 2010. This article is published with open access at Springerlink.com

\begin{abstract}
In answer to the criticism of binary distinctions of the last decades, my theoretical argument in this paper is that on the cognitive level we are strongly in need of binarism. In my approach binarism is not identical with ontological dualism. It pertains to world orientation, because without the cognitive tools of differentiation life would be characterized by entropy. In order to define their place in the world individuals are in continuous search for identity and difference. A following step is to be vigilant from an ethical perspective not to grant a one-sided value to one of the binary concepts at the expense of the other. It is the concern of cultural stereotyping which has elicited the criticism of binary distinctions. However, ethical commitment cannot do without the tools of cognition. Coming to literature, I discuss the binary terms of (historical) fact and fiction. Analyzing Romain Gary's La Danse de Gengis Cohn, a satirical Holocaust novel, I want to demonstrate that it is the tension between fact and fiction that allows for ambiguity and irony, intellectual strategies that go beyond binarism while accepting it as an indispensible cognitive tool.
\end{abstract}

Keywords Cognition $\cdot$ Structuralism $\cdot$ Poststructuralism $\cdot$ Holocaust literature

In the humanities it is nowadays fashionable to criticize binarism, the underlying motivation being moral concern. It is not surprising that in particular literary scholars working in the field of feminist or postcolonial research usually are reluctant to accept binary distinctions. Their argument goes as follows: Binarism essentially implies evaluation and this unquestionably results in granting high value to one of the binary concepts at the expense of the other, the opposite one. Still more disturbing is the observation that in the course of time the respective evaluative positions of the terms settle and eventually turn into cultural and political stereotypes. The question, however, is whether such ethical commitment sufficiently legitimizes the denial of binarism or, to put it otherwise, whether there are no other means to do justice to ethical involvement.

E. Ibsch $(\bowtie)$

Kastanjelaan 177, 1185 MV Amstelveen, The Netherlands

e-mail: e.ibsch@hetnet.nl 
Thinking about the problem of the semantics of binarism, my feeling is that at the cognitive level we cannot do without it, but that at the same time the combination of the cognitive and emotional capacities of human beings may help to avoid one-sided value attributions. In the following paragraphs I will try to develop my argument.

To begin with, binarism in my approach is not identical with ontological dualism or theological Manichaeism. Both refer to the existence of two antithetical worlds that are irreconcilably opposed to each other. The cognitive view, on the contrary, pertains to world orientation and it is exactly this quality that contributes to overcome the ontological oppositions. Without the cognitive tools of differentiation life would be characterized by entropy. In order to define their place in the world individuals are in continuous search for identity and difference. Well-known for his system-theoretical approach in the sociology of knowledge, Niklas Luhmann argues in his book Gesellschaftsstruktur und Semantik (The structure of society and semantics) as follows: Without distinction no observation, no meaning, no action, and consequently no world, because the world can only be defined as an entity by way of differentiation (Luhmann 1989, p. 355). He quotes George Spencer Brown who in his contribution to logic invites human beings to fulfill their primary task, namely to "draw a distinction" (p. 354). Only if individuals accept this task, the unmarked space of the world can be transformed into a recognizable order of identities and differences. What is valid for the world as a whole is valid for individuals as well. Luhmann argues that a person needs differentiation in order to achieve individuality. Identity is possible only through the experience of difference (p. 242).

Linguists and literary scholars will recall the structuralist linguist Ferdinand de Saussure who with respect to semantic entities writes: "C'est la différence qui fait le caractère, comme elle fait la valeur de l'unité" (Saussure 1976, p. 168). It is true, linguistic structuralism has not remained uncontested in the course of time. However, even Jacques Derrida, one of the critics of Saussure, in his philosophical reflections on the neographism 'différance' ('with an a') relies heavily on pairs of oppositions, be it "only for their strategic convenience and in order to undertake their deconstruction at the currently most decisive point" (Derrida 1982, p. 12). To give you some examples of Derrida's use of binary oppositions in his Margins of Philosophy: The sign represents the presence in the absence; 'différance' as temporization, 'différance' as spacing; to be not identical, to be other, discernable; structural versus historical, and so on, and so forth. In his later writings which are characterized by a strong ethical commitment Derrida's criticism of binarism has evaporated.

To recognize the inevitability of binarism in cognition and linguistics does not mean, however, to deny that pairs of opposition are strongly related to each other. This goes so far that it is legitimate to claim that the tension caused by differentiation produces significance. Friedrich Nietzsche, for instance, describes 'polarity' as a movement alternately going into the direction of both union and separation. The result of this movement is that "light and darkness, bitter and sweet, are attached to each other like two wrestlers" (Nietzsche 1960: III, p. 371). Nietzsche's metaphor can be interpreted as an early attempt at deconstructing binarism while, at the same time, accepting it as an inalienable condition of human thinking and survival.

That it is not exaggerated to include survival here can be illustrated by a psychological perspective on the binary distinction of cognition and emotion. In the Handbook of Emotions (2000) Carroll Izard and Brian Ackerman put it as follows: "Although emotion feelings differ qualitatively from thought and decision processes, their cue-producing function typically recruits the cognitive system, rapidly and automatically. The integration or coordinated interaction of emotion and appropriate cognition produces adaptive 
behavior" (p. 256). The authors make clear how different entities are connected and influence each other whereas, at the same time, maintaining their position at different ends of a scale.

The linguist Robert de Beaugrande who, on the one hand, supports the theoretical position of Saussure but on the other wants to make it more dynamic, puts it as follows: "A more dynamic and productive sense would be that the function of an entity [...] is defined by the contribution it makes to and receives from the entities which it is not but which are relevant to its occurrence" (Beaugrande 1992, p. 23). He adds a remark which, in my view, can be read as the very invitation to include ethical commitments. The assumption that each perspective is mutually constitutive of the other opens according to him "a systematic potential for intervention and change" (ibid.).

Up to this point my reflections on the semantics of binarism have a rather abstract and more or less philosophical character. Let me now return to literary scholarship where, as we all know, binary oppositions abound. I concentrate on one of them, i.e. the opposition between fact (or document) and fiction. From different perspectives literary theorists, in search of a well-defined and unambiguous object of literary studies, developed various models of the fact/fiction opposition. One of the most influential models was the linguistic one which aimed at defining a 'poetic language' as superposed on the primary linguistic system of ordinary language. These attempts include the Anglo-American theories of deviant language use and the poetic function theory of Roman Jakobson (1960), which was expressed in the well-known formula that in literature the poetic function projects the principle of equivalence from the axis of selection onto the axis of combination. Jakobson's theoretical proposal appeared to be a very strong candidate and, even today, has not lost its heuristic and analytical power. If we realize that the principle of repetitions and internal references on the different linguistic levels in literature is a way of compensating the reduction or loss of external references, we can easily agree with Beaugrande's idea of binary distinctions as "mutually constitutive."

Much more exclusive and less widely known is the "possible world theory' of literature as discussed, for example, by Thomas Pavel and Ruth Ronen. In its strongest version, the so-called 'segregationist view,' it denies that the fictional world has the status of a possible world, arguing that counterfactuals as alternatives are only valid within the range of the probabilities of our actual world. To complete my short overview of proposals that ground their definition of fiction on the principle of binary distinctions, one could add the speechact theory of John Searle who conceives of literary language as "pretended speech."

It is not by accident that the theories I mentioned appeared simultaneously with structuralism. With the rise of post-structuralism, binary models were severely attacked, without, as I mentioned with reference to Derrida, being totally abandoned. The fictional benefited from the radical arguments of post-structuralist philosophy. In a world where "il n'y a pas de hors texte" (to quote Derrida), there is no place for extra-linguistic facts. The subjective perspective, the unconscious, or the fictional undermine the factual in the scientific as well as in the historical discourse. The 'narrativist historians' (i.e. Hayden White) point to the principles of selection, expansion, condensation, to the conventions of genres, and other narrative procedures in order to consolidate their claims that fact and fiction cannot longer be separated. For literary scholars this was a welcome message. Indeed, it strengthened the importance of literature and promised the end of its marginal status.

In my opinion, however, there is no need to abandon the binary distinction between historical fact and literary fiction. On the contrary, only by maintaining the opposition as a cognitive tool one will be capable to do justice to the potential of literature in our world. This, however, presupposes a dynamic view of a mutual influence of one term on the other. 
Claiming extreme fictionality for literature would have the consequence of making it harmless and, at the same time, would exclude literary genres that are relatively close to historical reality. If we want to profit from the concept of the fictional as opposed to the factual we should conceive of it as a creative possibility within the boundaries of our 'real world' experiences. The fictional world has the power to provide the historical or actual world with a new, often unexpected context. It places part of our well-known world into a fictional one by connecting both sides via procedures of linguistic foregrounding as described by Roman Jakobson or Jurij Lotman. Knowledge of the historical context on the one hand and the capability of identifying the fictional elements on the other make reading an adventurous endeavor, opening the reader's mind for alternative worlds. Without the binary terms of fact and fiction this experience would not be possible, as it depends on the reader's awareness of confrontation and dialogue between history and imagination.

\section{An analysis of Romain Gary's La Danse de Gengis Cohn}

Certainly there is agreement that in Holocaust literature the tension between fact and fiction is always present. In this part of my paper I will elaborate on my research on this corpus from the perspective of the binarism of fact and fiction (Ibsch 2004).

The first writers dealing with the Holocaust after World War II were survivors of the concentration camps. Their testimonies aimed at informing the world about the historical facts of the genocide and, at the same time, trying to liberate themselves from the traumatic experiences they had gone through. Their documentary writings were the only accepted genre because of the gap between the realities of the Holocaust and imagination. However, as time went on, it could no longer be expected that the number of eyewitness reports would still substantially grow. In the course of the 1980s a change occurred: children of the survivors took the floor. They knew the world of the concentration camps only from the stories told by their parents and grandparents, from guessing if there was silence about the past, or from published documents and visible monuments. Some of them claimed unrestricted fictional freedom to deal with the Holocaust. Others wished to respect the memory of the survivors by remaining close to the records that had been handed down. Nowadays, the literary discourse of the Holocaust, characterized by a combination of historical authenticity and imagination, consists of a wide range of impressive works subscribing to the poetics of realism as well as to postmodern experimentation.

However many fictional elements may enter Holocaust literature, it will nevertheless not abandon its historical background. To make this ambiguity perceptible I have introduced the term imagined history indicating the inevitable rapport between the binary terms of history and imagination. This relation does not wipe out the original binarism of the two terms. On the contrary, respecting the binarism of history and imagination as the conditio sine qua non enables readers and critics to analyze and evaluate novels, plays, films, or poems with a maximum of competence and generosity. To give an example: if writers of imagined history choose the ironical mode or the genre of satire, it is of the highest importance that the readers have the competence to differentiate between fact and fiction.

Allow me to elaborate on the poetics of irony in Holocaust literature. Irony (including self-irony) is an eminently cognitive strategy of coping with negative experiences in life. The intellectual superiority inherent in the ironic competence may have a life saving function. The point is that the use of irony presupposes knowledge of the other and of oneself. It often plays a role in the mental representation of identity and alterity. Knowing the other has always been important for the survival of Jews in their long history of 
persecution and Diaspora. From the early beginnings of their migratory history Jews needed this knowledge to be able to settle within alien cultures (often Christian ones). Their failure, or better: their unconscious refusal to know the Germans in the beginning of the twentieth century prevented many Jews from leaving Germany in time. They admired the German culture and fostered the illusion of being completely part of it. After the disastrous experiences of World War II there was no illusion left. Only knowledge and, if necessary, the merciless analysis of the other will guarantee a life without being threatened. In my definition of irony I follow Sperber and Wilson's "Echoic-Mention-Theory," saying that irony results from a speaker attributing "a derogatory attitude to a meaning he or she merely mentions" (Sperber 1984, p. 130). I rephrase the definition and propose that irony results from "the transfer of a linguistic utterance from a generally accepted context into a contrasting and not expected one."

Irony as a weapon of survival, including self-irony about one's illusions and disillusions, is a characteristic of many Jewish authors of the post-war generations. We can observe that even in survivor testimonies, as for example in the writings of Primo Levi, the danger of total loss of command over body and mind is prevented by ironically echoing the behaviour of the oppressor.

Imagined history often is the playground of genres in which irony is not restricted to certain paragraphs but infects instead the whole plot. One of these genres is the satirical grotesque. Novels belonging to this genre are deliberately anti-realistic and playfully carnivalesque in the sense of Michael Bakhtin, who interprets the carnival as a subversive reaction to an illegitimate display of power. Undermining the abuse of power means, as in the case of irony, to defend one's own dignity. The subversive answer to the claims of those in power mitigates the strong dichotomy of victim and victimizer, the self and the other, without however denying the dichotomy. In contradistinction to irony the grotesque is to a lesser degree purely intellectual but explores instead the corporeality of the protagonists.

A novel belonging to the genre of imagined history and at the same time being an ironical satire par excellence is La Danse de Gengis Cohn by Romain Gary, published 1967. The date of publication indicates that the imagined history of the Holocaust entered the literary scene rather early and is not restricted to the second and third generations. I should add, however, that Gary had no personal camp experiences. He was born in Russia but educated in France and during World War II served as an officer of the French army. After the German occupation he joined the airforce of De Gaulle in London. His novel is a provocative satirical play with Jewish and German identities. It is situated in West Germany in the 1960s. A former SS officer has gone through the denazification process and now occupies a leading position with the police. The past, however, has caught up with him. He has become possessed by a 'dybbuk,' a wandering soul. A Jew, named Gengis Cohn, whom he ordered to be shot in Auschwitz, has taken over his mind and body. Everything he does, says, or thinks is accompanied by Cohn's comments and he cannot but appropriate his dybbuk's opinions. This has far-reaching consequences: the German officer is able to speak some Yiddish, to recite Caddish, and to prepare kosher food. The symbiosis has a double ironical function in Gary's political satire: the German protagonist unwillingly and with a certain amount of shame echoes the Jewish cultural discourse, whereas the Jewish protagonist, more aggressively, echoes the national socialist political program and the German cultural pretensions. Germany, Cohn says, that wanted to get rid of all Jews is entirely 'enjuivé.' The attempt to destroy all Jewish identity had the opposite result. After the Holocaust the Jewish identity is an integral part of German identity. The word 'Jew' will forever be associated with the word 'German.' This is symbolised by the officer and 
Cohn, who cannot exist without each other. Their intimate relationship, however, is and always will be an obscene one and never will end in reconciliation or friendship. Cohn reacts vehemently to the slightest attempt of fraternisation. His immediate self-defence is falling back upon the historical position of the Jew that has been encoded in negative stereotypes in everyday language as well as in literature and the visual arts.

Romain Gary felt free to put the Jewish discourse into the mouth of the perpetrator, an ironic device that we do not see in testimonial writings. However, the author makes use of a protective procedure to warrant nevertheless that the distance between victim and victimizer remains unimpaired. In La Danse de Gengis Cohn the narrator is the dybbuk who is permanently in control of what the German officer says.

The strong critical intention of Gary's novel can only be understood by a reader who is perfectly aware of the author's playing with fact and fiction, including stereotypes. The reader's capabilities to distinguish between Jewish and German identity and to understand its interchangeable assignation by the author is a prerequisite for understanding the ethical impulse behind the novel. A denial or deconstruction of binarism on the cognitive level would prevent access to the moral commitment characteristic of satirical writing.

In conclusion I strongly feel that we need binarism to go beyond it. Willingly admitting that the significance of literature is beyond binarism, I nevertheless strongly support binary distinctions, such as fact and fiction, self and other, irony and non-irony as cognitive tools enabling us to understand the de- and re-contextualization of historical reality in fiction. The necessarily subjective perspective of historians and the possibly distorted memory of eyewitnesses who rework their past in the present, are no arguments against binary distinctions. As I said already, I do not defend ontological dualism or theological Manichaeism with their absolute implications. I defend instead the capability of human beings to differentiate in life, ethics, the arts, and scientific research.

Open Access This article is distributed under the terms of the Creative Commons Attribution Noncommercial License which permits any noncommercial use, distribution, and reproduction in any medium, provided the original author(s) and source are credited.

\section{References}

Beaugrande, R. (1992). "The Heritage of Functional Sentence Perspective from the Standpoint of Textlinguistics." Linguistica Prageniensa 34, no. 1: 2-26, no. 2: 55-86.

de Saussure, F. (1976). Cours de linguistique générale. T. de Mauro (Ed.). Paris: Payot.

Derrida, J. (1982). Margins of philosophy (A. Bass, Trans.). Brighton, Sussex: The Harvester.

Ibsch, E. (2004). Die Shoah erzählt: Zeugnis und Experiment in der Literatur. Tübingen: Niemeyer.

Izard, C. E., \& Ackerman, B. P. (2000). Motivational, organizational, and regulatory functions of discrete emotions. In M. Lewis \& J. M. Haviland-Jones (Eds.), Handbook of emotions (2nd ed., pp. 253-264). New York, London: The Guilford.

Jakobson, R. (1960). Linguistics and poetics. In T. A. Sebeok (Ed.), Style in language (pp. 350-378). Cambridge Mass: M.I.T. Press.

Luhmann, N. (1989). Gesellschaftsstruktur und Semantik: Studien zur Wissenssoziologie der modernen Gesellschaft (Vol. 3). Frankfurt a. Main: Suhrkamp Verlag.

Nietzsche, F. (1960). Werke (Vol. 3). In K. Schlechta (Ed.), München: Hanser Verlag.

Romain, G. (1967). La Danse de Gengis Cohn. Paris: Gallimard.

Sperber, D. (1984). Verbal irony: Pretence of echoic mention? Journal of Experimental Psychology: General, 113(1), 130-136. 